\title{
PROBLEM WIELOŚCI SANKCJI REPRESYJNYCH ZA NIESZCZEPIENIE DZIECKA Z PERSPEKTYWY SKUTECZNEGO WYKONANIA OBOWIĄZKU SZCZEPIEŃ
}

\section{WPROWADZENIE}

Prawo do życia i zdrowia stanowi podstawowe prawo człowieka przynależne mu w związku z poszanowaniem godności osoby ludzkiej, przez sam fakt, że jest człowiekiem. Szczególna ochrona prawna w tym zakresie należy się dziecku, o czym stanowi art. 68 ust. 3 Konstytucji Rzeczypospolitej Polskiej ${ }^{1}$ : wymieniono w nim dzieci jako pewną uprzywilejowana grupę społeczna, nad która ustrojodawca roztoczył prawo do szczególnej opieki zdrowotnej. W zakresie tego prawa funkcjonuje także ochrona przed rozprzestrzenianiem się chorób zakaźnych, która realizowana jest między innymi przez ustawowy obowiązek szczepień ochronnych.

Chociaż nawet w literaturze prawniczej podkreśla się, że jest to najskuteczniejsza profilaktyka chorób zakaźnych ${ }^{2}$, to obowiązek szczepień ochronnych $\mathrm{w}$ debacie społecznej odbierany jest wielorako. Jednym z argumentów przeciwników szczepień jest to, że ogranicza on swobodę w wychowywaniu dzieci. Podkreśla się także ryzyko, jakie niesie za sobą zaszczepienie (w tym niepożądane odczyny poszczepienne). Powoduje to spadek wyszczepialności na terenie Polski, co zauważalne jest w statystykach opracowywanych przez Państwowy Zakład Higieny $(\mathrm{PZH})^{3}$, badaniach przeprowadzanych przez

* Sebastian Czechowicz, Uniwersytet Łódzki, sebastian.czechowicz@edu.uni.lodz.pl https://orcid.org/0000-0002-1770-1941.

${ }^{1}$ Dz. U. 1997, Nr 78, poz. 483.

${ }^{2}$ Karczewska-Kamińska (2018): 197.

${ }^{3}$ Coroczne meldunki dostępne na: <http://wwwold.pzh.gov.pl/oldpage/epimeld/index_p.html>. 
Centrum Badania Opinii Społecznej (CBOS) ${ }^{4}$ i raportach Państwowej Inspekcji Sanitarnej ${ }^{5}$.

Wobec procederu uchylania się od obowiązkowych szczepień ochronnych dzieci stosowane sa sankcje administracyjne i na gruncie prawa wykroczeń. Sankcje te w swym założeniu maja zabezpieczać prawidłowe wykonywanie obowiązkowych szczepień ochronnych. Jednocześnie nie tworzą one ścisłego korelatu, przez co problem pojawia się w trakcie egzekwowania obowiązku zaszczepienia dziecka, od którego uchylili się jego przedstawiciele ustawowi. Istotna w tym zakresie jest problematyka sankcji administracyjnej i odróźnienie jej od sankcji karnej zapadłej na gruncie prawa wykroczeń, co stanowi rdzeń problemu omówionego w niniejszej pracy.

\section{PROCEDER UCHYLANIA SIĘ OD OBOWIĄZKU SZCZEPIEŃ}

Obowiązkowe szczepienia ochronne od lat budzą wiele kontrowersji w polskiej przestrzeni publicznej. Szacuje się, że obecnie w Polsce odsetek zaszczepionych wynosi około $95 \%$. W porównaniu z innymi państwami sytuacja epidemiologiczna jest stabilna i przez Główny Inspektorat Sanitarny oceniana jako dobra. Jednakże tendencja szczepień dzieci uległa widocznemu zachwianiu. Zjawisko uchylania się od obowiązkowych szczepień ochronnych jest coraz bardziej widoczne w statystykach. Niestety ciężko dostrzec wymierne reakcje legislacyjne ze strony prawodawcy.

Z materiałów sporządzonych przez służby sanitarne oraz Najwyższą Izbę Kontroli wynika, że w Polsce odnotowuje się znaczący wzrost popularności tzw. ruchów antyszczpionkowych. Ich przedstawiciele odmawiają poddawania się obowiązkowym szczepieniom ochronnym, a w przypadku wdrażania środków egzekucji tej powinności, podejmują batalie sądowe. Zjawisko to jest niebezpieczne, gdyż prowadzi do spadku liczby osób zaszczepionych, co w efekcie może prowadzić do powrotu szeregu groźnych, a nawet śmiertelnych chorób (np. odry). Także w dobie pandemii COVID-19 unikanie obowiązkowych szczepień ochronnych dzieci na choroby już znane naraża je na dodatkowe niebezpieczeństwo zarażenia.

Zjawisko uchylania się od obowiazkowych szczepień ochronnych to nie tylko problem prawny, lecz także społeczny. W wymiarze ponadnarodowym borykają się z nim niektóre państwa. Dla porównania, w państwach europejskich i USA spadek osób zaszczepionych spowodował rozkwit wielu groźnych chorób zakaźnych w ciągu ostatnich lat ${ }^{6}$. Przeprowadzone w USA badania jednoznacznie wskazuja, że nieszczepienie prowadzi do wzrostu wskaźników

\footnotetext{
${ }^{4}$ Komunikaty z badań opinii społecznej na temat szczepień przeprowadzone przez CBOS zob. <https://cbos.pl/SPISKOM.POL/2019/K_009_19.PDF>; <https://www.cbos.pl/SPISKOM. POL/2017/K_100_17.PDF>.

${ }^{5}$ Coroczne raporty Głównego Inspektoratu Sanitarnego „Stan Sanitarny Kraju”, <https:// www.gov.pl/web/gis/raport---stan-sanitarny-kraju>.

${ }^{6}$ Riccardi, Boccia, Silquini (2018): 2.
} 
zachorowań na wiele chorób ${ }^{7}$. Należy wskazać, że państwa europejskie doświadczone tym zjawiskiem powracają do szczepień ochronnych. Przykładowo we Francji od 2018 r. istnieje 11 obowiązkowych szczepień ochronnych. We Włoszech natomiast począwszy od 2017 r. wprowadzono 10 kolejnych obowiązkowych szczepień dla dzieci do 16 roku życia, a w Słowenii - $9^{8}$.

W związku z powyższymi zjawiskami tym bardziej aktualne sa apele podnoszone przez instytucje państwa zajmujące się ochroną dziecka. Rzecznik Praw Dziecka odniósł się w ubiegłym roku do tendencji uchylania się od obowiązkowych szczepień ochronnych, podkreślając, że są one najskuteczniejszym narzędziem zwalczania chorób zakaźnych. Ponadto wart podkreślenia jest fakt, że w ostatnich latach coraz więcej rodziców nie zgadza się na nie. Z informacji Narodowego Instytutu Zdrowia Publicznego - Państwowego Zakładu Higieny wynika, że w roku 2010 zanotowano 3437 odmów, w 2017 - już 30089 odmów9. Jak wskazał Główny Inspektor Sanitarny, spadek liczby zaszczepionych do poziomu 80-85\% spowoduje powrót chorób, które dotychczas były skutecznie zwalczane, a nawet istniała nadzieja na ich wyeliminowanie ${ }^{10}$.

Organy państwa powinny zatem podejmować działania ukierunkowane na zniwelowanie takich postaw. Pomimo wyżej wspomnianych kontrowersji problematyka wyegzekwowania obowiązku szczepień jest pomijana i stanowi „czystą kartę” do prowadzenia badań w tym aspekcie. Analizując problem społeczny, jaki stanowi uchylanie się od obowiązkowych szczepień ochronnych, dotrzeć należy do efektywnych rozwiązań prawnych, jednocześnie możliwych do zrealizowania w praktyce stosowania prawa.

Uchylanie się od obowiązkowych szczepień ochronnych nie jest uregulowane w przepisach szeroko rozumianego prawa administracyjnego. Ustawa o zapobieganiu oraz zwalczaniu zakażeń i chorób zakaźnych u ludzi ${ }^{11}$ konstytuuje jedynie sam obowiązek poddania się szczepieniom ochronnym przez określony krag podmiotów ${ }^{12}$. W przedmiotowej ustawie na próżno szukać sankcji przymuszającej do wykonania tego obowiązku. Jest w niej mowa o samym obowiąku, wprost wykonywalnym ${ }^{13}$. Fakt wykonywalności obowiązkowych szczepień ochronnych potwierdziło bogate orzecznictwo sądów administracyjnych w tym zakresie $^{14}$. Należy się spodziewać, że w związku ze znaczącym wzrostem od-

\footnotetext{
${ }^{7}$ Weithorn, Rubinstein Reiss (2018): $1611 \mathrm{n}$.

8 Walkinshaw (2011): 1167.

${ }^{9}$ Zob. biuletyny roczne PZH: <http://wwwold.pzh.gov.pl/oldpage/epimeld/index_p.html> [dostęp: 20.02.2020].

${ }^{10}$ Zob.<https://gis.gov.pl/zdrowie/stanowisko-krajowego-konsultanta-w-dziedzinie-zdrowiapublicznego-ws-obowiazku-szczepien/?fbclid=IwAR0cRqdjxnMe4e9V-uqOD04Efuv167PZtRVuid IBrGVWX5iuby2D1H37nB0> [dostęp: 20.02.2020].

11 T.jedn.: Dz. U. 2019, poz. 1495.

${ }^{12}$ Szczegółowe kryteria zawiera rozporządzenie Ministra Zdrowia z 18 sierpnia $2011 \mathrm{r}$. w sprawie obowiązkowych szczepień ochronnych, Dz. U. Nr 182, poz. 1086.

${ }^{13}$ Zob.: art. 5 ust. 1 pkt 1 lit. b w związu z art. 17 ust. 1 ustawy o zapobieganiu oraz zwalczaniu zakażeń i chorób zakaźnych u ludzi, t. jedn.: Dz. U. 2019, poz. 1495.

${ }^{14}$ Por. wyroki: NSA z 30 stycznia 2018 r., II OSK 2358/17, Lex nr 2451163; WSA w Poznaniu z 1 czerwca 2017 r., IV SAB/Po 22/17, Lex nr 2341062; WSA w Warszawie z 19 października 2016 r., VII SA/Wa 2539/15, Lex nr 2159949.
} 
setka osób niezaszczepionych orzeczeń tego rodzaju będzie z każdym rokiem przybywać ${ }^{15}$.

Należy zaznaczyć fakt, że obowiązek szczepień ochronnych jest obowiązkiem o charakterze niepieniężnym, wynikajaccym wprost z przepisów pra$\mathrm{wa}^{16}$. Od obowiązku nie można legalnie się uchylić poza przypadkiem stwierdzenia temporalnych przeciwskazań do wykonania szczepienia. Moga one być stwierdzone w badaniu kwalifikacyjnym, które także stanowi element samego obowiązku ${ }^{17}$. Co więcej, uchylanie się od obowiązkowych szczepień ochronnych stanowi wykroczenie, o czym stanowi art. 115 Kodeksu wykroczeń $^{18}$. Przesłanką odpowiedzialności za to wykroczenie jest bezskuteczność egzekucji prowadzonej przez organy administracji publicznej. Okoliczność ta jest niezwykle istotna z punktu widzenia nakładania sankcji i zauważenia faktu przeniesienia ciężaru egzekucji tego obowiązku na wykonanie orzeczenia sądu karnego.

\section{CHARAKTER SANKCJI ADMINISTRACYJNOPRAWNEJ ZA NIESZCZEPIENIE DZIECKA}

Jak wskazano, sankcji administracyjnych nie odnajdziemy w ustawie o zapobieganiu oraz zwalczaniu zakażeń i chorób zakaźnych u ludzi. Podstaw prawnych do nakładania sankcji administracyjnych doszukać się można w ustawie z 17 czerwca 1966 r. o postępowaniu egzekucyjnym w administracji ${ }^{19}$, a konkretnie w art. $119 \S 1$. Stanowi on, że grzywnę w celu przymuszenia nakłada się w przypadku, gdy egzekucja dotyczy spełnienia przez zobowiązanego obowiązku znoszenia lub zaniechania albo obowiązku wykonania czynności, a w szczególności czynności, której z powodu jej charakteru nie może spełnić inna osoba za zobowiązanego. O charakterze tej sankcji administracyjnej wypowiedział się Wojewódzki Sąd Administracyjny w Warszawie w wyroku z 19 października 2016 r., w którym stwierdził, iż nałożona grzywna nie stanowi kary, lecz formę przymuszenia zobowiązanego podmiotu do wykonania ciążącego na nim obowiązku ${ }^{20}$. Zatem sankcja administracyjnoprawna polega na przymuszeniu do wykonania obowiązkowych szczepień ochronnych dziecka, a nakładana jest na rodziców lub opiekunów prawnych małoletniego. Ponadto organem administracji publicznej władnym do prowadzenia postępowania egzekucyjnego jest Państwowa Inspekcja Sanitarna, co potwierdziły

${ }_{15}$ Według szacunków NIZP - PZH liczba osób niezaszczepionych każdego roku wzrasta. Z blisko $3500 \mathrm{w}$ roku 2010 wzrosła do ponad $40000 \mathrm{w} 2018$ (dane na podstawie raportów PZH dostępnych na: <http://wwwold.pzh.gov.pl/oldpage/epimeld/index_p.html> [dostęp: 10.02.2020]).

${ }^{16}$ Szerzej: Karczewska-Kamińska (2018): $200 \mathrm{n}$.

17 Zob. wyroki: WSA w Warszawie z 30 kwietnia 2019 r., VII SA/Wa 2698/18, Lex nr 2699994; NSA z 6 czerwca 2017 r., II GSK 2398/15, Lex nr 2347675.

18 T.jedn.: Dz. U. 2019, poz. 1238 (dalej jako: k.w.).

19 T.jedn.: Dz. U. 2019, poz. 2070 (dalej jako: u.p.e.a.).

${ }^{20}$ Wyrok WSA w Warszawie z 19 października 2016 r., VII SA/Wa 2537/15, Lex nr 2090334. 
niejednokrotnie sądy administracyjne ${ }^{21}$. Należy podkreślić, że obowiązek ten jest stosowany wprost z przepisów ustawy bez konieczności jego konkretyzacji w formie decyzji administracyjnej ${ }^{22}$.

W nałożonej na podstawie art. 119 § 1 u.p.e.a. sankcji administracyjnej nie należy doszukiwać się funkcji represyjnej, która występować będzie przy wymierzaniu kary, chociażby na podstawie art. $115 \mathrm{k}$.w. Świadczyć o tym może chociażby możliwość wielokrotnego nakładania tejże sankcji, co w przypadku gdyby była karą za niewykonanie obowiązku, kłóciłoby się z zasadą ne bis in idem. Każdorazowo grzywna w celu przymuszenia do wykonania obowiązkowych szczepień ochronnych dzieci wynosić może jednorazowo do 10000 zł. Jednakże łączna suma nałożonych grzywien nie może przekroczyć kwoty 50000 zł ${ }^{23}$.

Komentując charakter tej sankcji administracyjnej, zauważyć także należy, że grzywna w celu przymuszenia powinna być nakładana jako ostateczny środek egzekucyjny, po wyczerpaniu możliwości stosowania innych środków egzekucyjnych. Poprzeć należy pogląd, że sankcja, jaką jest grzywna w celu przymuszenia, jako środek egzekucyjny o charakterze przymuszającym jest bez wątpienia środkiem mniej uciążliwym niż pozostałe środki egzekucyjne stosowane w egzekucji obowiązków o charakterze niepieniężnym ${ }^{24}$. Jest to wyrazem zasady stosowania najmniej uciążliwego środka egzekucyjnego, gdyż na podstawie art. $7 \S 2$ u.p.e.a. organ egzekucyjny winien posługiwać się środkiem, który prowadzi bezpośrednio do wykonania obowiązku i jest dla zobowiązanego najmniej dotkliwy (inaczej jest najłagodniejszym środkiem egzekucyjnym) ${ }^{25}$. Należy zaznaczyć, że wspomniana ustawa nie wymienia środków, które są mniej lub bardziej dolegliwe dla zobowiązanego, zatem to organ administracji publicznej będzie władny dokonać oceny, który środek będzie najmniej uciążliwy w konkretnej sytuacji. Omawiana sankcja będzie więc posiadała funkcję wywarcia presji na podmiot zobowiązany, a więc rodziców bądź opiekunów prawnych dziecka, by dobrowolnie poddać małoletniego obowiązkowemu zaszczepieniu.

Zasadny jest wniosek, że sankcja administracyjna w zakresie egzekwowania obowiązku szczepień ma charakter sankcji egzekucyjnej, nie nosi więc cech represji (jak w przypadku chociażby kary kryminalnej). Trudno także dostrzec w niej przymiot kary, gdyż może zostać uchylona z chwila spełnienia obowiązu. Ma ona natomiast wszelkie warunki, by spełnić kryterium sankcji ukierunkowanej na spełnienie obowiązku prawnego ciążącego na obowiązanym podmiocie, czyli pewnej negatywnej dolegliwości uregulowanej prawem, której celem jest skłonienie uchylającego się podmiotu do spełnienia obowiązku.

${ }^{21}$ Zob. np. wyroki: WSA w Warszawie z 20 września 2017 r., VII SA/Wa 2389/16, Lex nr 2437980; WSA w Białymstoku z 16 kwietnia 2013 r., II SA/Bk 89/13, Lex nr 1310133; WSA w Olsztynie z 6 listopada 2012 r., II SA/Ol 839/12, Lex nr 1241147.

${ }^{22}$ Wyrok WSA w Warszawie z 11 grudnia 2019 r., VII SA/Wa 2061/19, Lex nr 2771524.

23 Art. 121 u.p.e.a.

24 Przybysz (2018): $584 \mathrm{n}$.

25 Grześkiewicz (2006): 55. 
Rozbicie prawnych podstaw funkcjonowania obowiązkowych szczepień ochronnych na wiele aktów prawnych nastręcza znacznych trudności w praktyce stosowania prawa. Należy mieć na uwadze, że niezaszczepione dziecko pozostaje narażone na biologiczne czynniki chorobotwórcze wywołujące choroby zakaźne, przeciwko którym należało dziecko zaszczepić. Tym samym wydłużający się proces egzekucji obowiązku staje się realną przyczyną wzrostu zachorowań na określoną chorobę zakaźną u niezaszczepionej części społeczeństwa. Wypada stwierdzić, że efektywność obowiązku szczepień determinowana będzie szybkością jego wykonywania bądź egzekwowania, a także wymierzaniem i egzekwowaniem sankcji administracyjnych.

Należy zauważyć, że powyższe sankcje natury administracyjnoprawnej mają na celu skłonienie uchylającego się podmiotu do wykonania obowiązku. Nie są zatem karą za uchylanie się od obowiązkowych szczepień ochronnych. Sankcję za uchylanie się od szczepień odnaleźć można w dopiero w prawie wykroczeń. To rozbicie regulacji prawnych odnoszących się do obowiązkowych szczepień ochronnych prowadzi do rozmycia jednolitości samego obowiazku, a także nasuwa wątpliwości co do efektywności stosowania obecnych regulacji prawnych go kształtujących.

\section{ROLA SĄDU KARNEGO W REALIZACJI OBOWIĄZKOWYCH SZCZEPIEŃ OCHRONNYCH DZIECI}

Uchylanie się od obowiązkowych szczepień ochronnych stanowi wykroczenie stypizowane w artykule 115 k.w., który w $§ 1$ określa, że kto, pomimo zastosowania środków egzekucji administracyjnej, nie poddaje się obowiązkowemu szczepieniu ochronnemu przeciwko grú́licy lub innej chorobie zakaźnej albo obowiązkowemu badaniu stanu zdrowia, mającemu na celu wykrycie lub leczenie gruźlicy, choroby wenerycznej lub innej choroby zakaźnej, podlega karze grzywny do 1500 złotych albo karze nagany. Artykuł 115 $\S 2$ k.w. rozciaga odpowiedzialność za czyn z paragrafu poprzedzającego na każdego, kto sprawując pieczę nad osobą małoletnią lub bezradna, pomimo zastosowania środków egzekucji administracyjnej, nie poddaje jej określone$\mathrm{mu} \mathrm{w} \S 1$ szczepieniu ochronnemu lub badaniu. Istotne jest wprowadzenie warunku uprzedniego zastosowania środków egzekucji administracyjnej, co bezpośrednio łączy omawiane wykroczenie z działalnością administracji publicznej ${ }^{26}$. Ponadto wykazuje konieczność wcześniejszego podjęcia środków

\footnotetext{
${ }^{26}$ Szeroko rozumiane współczesne prawo wykroczeń wyodrębniono z kompetencji administracji publicznej i przeniesiono na grunt prawa karnego sensu largo. Jednakże w doktrynie pojawiają się stanowiska o istnieniu prawa administracyjno-karnego. Wykazuje się ciągłe związki pomiędzy administracją publiczną a prawem wykroczeń i toczy się dyskusja o możliwości ujmowania organów administracji publicznej przez pryzmat ich ewentualnych kompetencji natury represyjnej. Zob. Szumiło-Kulczycka (2004): 30 n.; Błachnio-Parzych (2016): 19 n.; Danecka (2018): $99 \mathrm{n}$.
} 
egzekucji administracyjnej, czyli zastosowania wspomnianej wcześniej sankcji administracyjnoprawnej.

Warto zaznaczyć, że przedmiotem ochrony w przypadku czynów określonych w art. $115 \mathrm{k} . \mathrm{w}$. jest szeroko rozumiane zdrowie społeczeństwa i poszczególnych jednostek. To dobro prawne może zostać narażone przez rozwijające się ogniska chorób zakaźnych na skutek uchylenia się od obowiązkowych szczepień ochronnych. W odniesieniu do dziecka jako podmiotu szczególnie chronionego prawem istotny będzie $\S 2$ omawianego artykułu. Penalizuje on rodziców lub opiekunów prawnych dziecka, którzy sprawując pieczę ${ }^{27}$ nad osobą małoletnią lub bezradna, uchylają się od poddania tej osoby obowiązkowym szczepieniom ochronnym. W tym przypadku zdecydowanie należy przyjać, że oprócz społeczeństwa i innych jednostek chronione jest przede wszystkim zdrowie dziecka ${ }^{28}$. Warto podkreślić trafną ocenę Marii Boratyńskiej, która stwier$\mathrm{dza}$, że osoba nieszczepiona stwarza zagrożenie epidemiczne a priori. Z tego bowiem względu, że osoba taka sama jest narażona na zakażenie i w każdej chwili jest w stanie to zakażenie przenieść na inne osoby ${ }^{29}$.

Wspomniana przesłanka uprzedniego zastosowania środków egzekucji administracyjnej jest konieczna do aktualizowania się odpowiedzialności z art. 115 k.w. Na mocy tego przepisu nie określono jednak, w którym dokładnie momencie należy skierować wniosek o ukaranie. Rozważając wszystkie przypadki zastosowania sankcji w postaci grzywny w celu przymuszenia do wykonania obowiązku, przeniesienie ciężaru dalszej egzekucji obowiązku szczepień na sąd karny może nastąpić, gdy:

1) zastosowano środki egzekucji administracyjnej w postaci grzywny w celu przymuszenia do wykonania obowiązku - wówczas wystarczy co najmniej dwukrotnie nałożyć grzywnę na obowiązany podmiot, by spełnić przesłankę ustawową określoną liczbą mnogą (,środków egzekucji administracyjnej”), lub

2) zastosowano środki egzekucji administracyjnej w postaci grzywny w celu przymuszenia do wykonania obowiązku i jednocześnie wykorzystano możliwość zastosowania tego środka - jeśli bowiem grzywna jednorazowo może opiewać na kwotę do 10000 zł, a maksymalna kwota nałożonych grzywien nie może przekroczyć $50000 \mathrm{zł}$, to dopiero w momencie wyczerpania tej możliwości organ administracji publicznej może wystapić z wnioskiem o ukaranie na mocy art. $115 \mathrm{k} . w$. - a zastosowanie tych środków nie przyniosło spełnienia obowiązku poddania dziecka obowiązkowemu zaszczepieniu.

Rezultat powyższego rozróżnienia jest w zasadzie jeden: to organ administracji publicznej może wybrać moment, gdy skieruje wniosek o ukaranie. Jest to o tyle zasadne, że sam Kodeks wykroczeń nie określa przesłanki „wyczerpania drogi egzekucji administracyjnej”, lecz „zastosowania środków egzekucji administracyjnej”. W tym stanie rzeczy możemy uznać, że obie zaproponowane wyżej możliwości są jak najbardziej zasadne. Istnieje więc obawa o jednoli-

${ }_{27}$ Poprzeć należy stanowisko, że rozumienie pojęcia pieczy powinno w tym przypadku obejmować pieczę zarówno w sensie prawnym, jak i faktycznym. Por. Zbrojewska (2013): 536.

28 Por. Michalska-Warias (2020).

29 Boratyńska (2019): 755. 
tość stosowania sankcji administracyjnych, a także o ich stosowanie w ogóle. Duża swoboda decyzyjna organu administracji publicznej może bowiem powodować wydłużenie procesu egzekwowania obowiązu szczepień, co naraża niezaszczepione dziecko na zachorowanie.

Zasadność powyższych rozwiązań przesądza jednocześnie o problemie aktualizacji normy przepisu art. $115 \mathrm{k}$.w. Sprowadza się ona do uznaniowości, kiedy wystapić z wnioskiem o ukaranie. W różnych stanach faktycznych, lecz przy tym samym obowiąku organy administracyjne moga zatem postapić różnie. Należałoby postulować zmianę przepisu na bardziej precyzyjny, jak na przykład wspomniana przesłanka wyczerpania drogi egzekucji administracyjnej. Być może - per analogiam do tak zwanego przestępstwa niealimentacji (art. 209 k.k.) ${ }^{30}$ - znamię uporczywości uchylania się byłoby także stwierdzeniem trafnym, lecz już ocennym i nieostrym w przypadku braku dalszego doprecyzowania. Dostrzec można zatem co najmniej kilka propozycji modyfikacji istniejących przepisów wykroczeniowych $\mathrm{w}$ tym zakresie. Przesłanką naczelna, przemawiająca za koniecznością zmian regulacji prawa wykroczeń, jest konieczność ujednolicenia prawnego modelu obowiązkowych szczepień ochronnych w Polsce dla zwiększenia jego efektywności.

Odnoszac się jednak do aktualnego brzmienia przepisu art. 115 k.w., warto zauważyć swoiste przeniesienie zadań administracji publicznej na sąd karny. Otóż sąd w postępowaniu w sprawie o wspomniane wykroczenie będzie decydował o zawinieniu, a przez to o sankcji na gruncie prawa wykroczeń za nieszczepienie. Będzie tak w przypadku, gdy organy administracji publicznej nie będa w stanie skutecznie wyegzekwować poddania dziecka obowiązkowemu szczepieniu ochronnemu. Wówczas wraz z wystapieniem z wnioskiem o ukaranie wydaje się, że dalsze egzekwowanie obowiązku szczepień zostaje przekazane w gestię sądu karnego na etapie wykonywania orzeczenia.

Stwierdzić należy, że proponowany katalog sankcji za to wykroczenie jest symboliczny w odniesieniu do dobra prawnego, które maja chronić. Co więcej, w porównaniu z maksymalną sumą grzywien nakładanych w celu przymuszenia do wykonania obowiązkowego szczepienia ochronnego sankcje znajdujące się w art. $115 \mathrm{k} . w$. ocenić trzeba negatywnie. Przez to przepis ten traci na efektywności. Funkcja ochronna prawa karnego sensu largo przejawiająca się w każdej regulacji typizującej czyn zabroniony pod groźbą kary również stoi pod znakiem zapytania. W obliczu coraz większego problemu uchylania się od obowiązkowych szczepień ochronnych także funkcja represyjna ewentualnych sankcji jest wysoce wątpliwa.

Pozytywnych elementów należy się doszukiwać w res iudicata orzeczenia sądu karnego, które podlega wykonaniu. Wówczas pomimo nałożenia kary sąd powinien nakazać wykonanie obowiązku. Jednakże niezwykle trudno o przykłady statystyczne związane zarówno z liczbą wydawanych orzeczeń, jak i szybkością orzekania w kontekście ryzyka narażenia na zarażenie chorobami zakaźnymi.

${ }^{30}$ Ustawa z 6 czerwca 1997 r. - Kodeks karny, t.jedn.: Dz. U. 2020, poz. 1444. 


\section{PODSUMOWANIE I POSTULATY DE LEGE FERENDA}

Problem uchylania się od obowiązku szczepień dzieci jest coraz bardziej powszechny. Stanowi on problem natury nie tylko społecznej, lecz także prawnej. Mimo to zauważalna jest marginalizacja problemu, co w aktualnej rzeczywistości międzynarodowej jest wysoce lekceważące. Rozprzestrzenianie się chorób zakaźnych rokrocznie przybiera na znaczeniu. Powinno to powodować dostosowywanie regulacji prawnych, przy jednoczesnym zwracaniu szczególnej uwagi na ich efektywność oraz dobra prawne, które mają chronić.

Sankcje administracyjne w przypadku uchylania się od nałożonego obowiązku zdecydowanie są nieefektywne, co można wywnioskować po samych statystykach PZH, bez szczególnego zagłębiania się w przedmiotową materię. Jednakże ustawodawca w dalszym ciagu nie podjął kroków mających na celu uzdrowienie tej sytuacji. W przypadku wykroczenia polegajacego na uchylaniu się od obowiązkowych szczepień ochronnych postulować należy pilną interwencję legislacyjną i przemyślenie ewentualnego przeniesienia tego wykroczenia do katalogu występków, ewentualnie rozważenie bardziej dolegliwych sankcji.

Zdecydowanie stwierdzić należy, że aktualny katalog sankcji represyjnych za nieszczepienie nie spełnia swoich funkcji. Świadczy o tym przede wszystkim wzrostowa tendencja odsetka niezaszczepionych. Z roku na rok liczba uchyleń od poddania dzieci obowiązkowym szczepieniom ochronnym wzrasta, co przełożyć się może na powrót niektórych chorób zakaźnych, ich rozprzestrzenianie się w społeczeństwie, a w efekcie powstawanie ognisk epidemicznych. Stąd też postulować należy weryfikację prawa w zakresie funkcjonowania i realizacji obowiązku szczepień ochronnych dzieci w celu jego usprawnienia i przyspieszenia. Wielość organów zaangażowanych w realizowanie obowiązkowych szczepień ochronnych, brak jednoznacznych kompetencji, nieprecyzyjne regulacje prawne, szeroka swoboda decyzyjna organu administracji publicznej $\mathrm{w}$ zakresie skierowania wniosku o ukaranie za wykroczenie z art. $115 \mathrm{k} . \mathrm{w}$. powoduja, że obowiązek szczepień ochronnych w praktyce tylko z nazwy pozostaje obowiązkiem, a w głównej mierze jego realizacja zależy od woli przedstawicieli ustawowych dziecka.

Oceniajac cały tok podejmowanych czynności od momentu uchylenia się od obowiązu do momentu wydania orzeczenia przez sąd karny, jednoznacznie należy wyrazić ubolewanie nad jego niską efektywnościa, która powoduje ostatecznie spadek wyszczepialności dzieci, co widoczne jest w aktualnych statystykach uchyleń od obowiązkowych szczepień ochronnych. W dobie światowej pandemii COVID-19 problem szczepień ochronnych na choroby już znane wydaje się coraz bardziej dostrzegalny, co wydaje się dobrze rokować na przyszłość.

Błachnio-Parzych, A. (2016). Zbieg odpowiedzialności karnej i administracyjno-karnej jako zbieg reżimów odpowiedzialności represyjnej. Warszawa.

Boratyńska, M. (2019). Postępowanie przymusowe, [w:] E. Zielińska (red.), System prawa medycznego. Tom 2. Część 1: Regulacja prawna czynności medycznych, red. M. Boratyńska, P. Konieczniak. Warszawa. 
Danecka, D. (2018). Konwersja odpowiedzialności karnej w administracyjną w prawie polskim. Warszawa.

Grześkiewicz, W. (2006). Egzekucja administracyjna - teoria i praktyka z orzecznictwem sądowoadministracyjnym. Warszawa.

Karczewska-Kamińska, N. (2018). Przymus leczenia i inne interwencje medyczne bez zgody pacjenta. Warszawa.

Michalska-Warias, A. (2020). Komentarz do art. 115 Kodeksu wykroczeń, [w:] T. Bojarski (red.), Kodeks wykroczeń. Komentarz. Warszawa: Lex/el.

Przybysz, P.M. (2018). Postępowanie egzekucyjne w administracji. Komentarz. Warszawa.

Riccardi, W., Boccia, S., Silquini, R. (2018). Moving towards compulsory vaccination: the Italian experience. European Journal of Public Health 128(1): 2-3.

Szumiło-Kulczycka, D. (2004). Prawo administracyjno-karne. Kraków.

Walkinshaw, E. (2011) Mandatory vaccinations: the international landscape. Canadian Medical Association Journal 183(16): 1167-1168.

Weithorn, L.A., Rubinstein Reiss, D. (2018). Legal approaches to promoting parental compliance with childhood immunization recommendations. Human Vaccines \& Immunotherapeutics 14: $1610-1617$.

Zbrojewska, M. (2013). Komentarz do art. 115 Kodeksu wykroczeń, [w:] T. Grzegorczyk (red.) Kodeks wykroczeń. Komentarz. Warszawa: 536-537.

\section{THE PROBLEM OF MULTIPLE REPRESSIVE SANCTIONS FOR NOT VACCINATING A CHILD FROM THE PERSPECTIVE OF EFFECTIVE IMPLEMENTATION OF THE VACCINATION OBLIGATION}

\section{Sum mary}

The mandatory vaccination of children raises a lot of controversy in the public space. Anti-vaccination movements have been increasingly active in recent years. The aim of this article is to present the problem of sanctions with regard to mandatory vaccination of children, around which a lot of social and legal controversy has arisen. Sanctions used in connection with the evasion of the obligatory preventive vaccination of children in Poland are analysed. The essence of administrative sanctions in the case of mandatory vaccination of children is considered, as well as the transfer of the execution of this obligation to criminal courts. It is pointed out that absolute distinction has to be drawn between the scope of possibilities of applying administrative sanctions in the course of enforcement proceedings in administration and those provided for in the petty offences law. An analysis of normative acts and the literature on the subject as well as court decisions concerning the presented problem is made. Using a dogmatic-legal method and an analysis of court rulings, it is established that the aim of the application of administrative-law sanctions may only be to compel a person to fulfil an obligation. On the other hand, penalties on the grounds of the petty offences law will be administered for the evasion of obligatory preventive vaccination of children in Poland.

Keywords: mandatory preventive vaccination; child; criminal sanctions; administrative sanctions 